\title{
Dialogue-Thermal Comfort: Investigation Through Body Behavior in Kampung Deret Petogogan
}

\author{
Kevin Tanamas ${ }^{1}$, Samsu Hendra Siwi ${ }^{1}$, Fermanto Lianto ${ }^{1}$, Martinus Bambang $\mathbf{S}^{1}$ \\ ${ }^{1}$ Department of Architecture, Tarumanagara University, Indonesia \\ sh.siwi@gmail.com
}

\begin{abstract}
This paper discusses the relationship between thermal comfort and human behavior found in RISHA House, a prefabricated house from the government for occupants in Kampung Deret Petogogan with a knockdown system. Thermal comfort is usually measured using a Thermal hygrometer. In this paper, the writer will focus more on analyzing the occupants' bodies' behavior in identifying comfortable spaces and thermal discomfort to obtain subjective and objective data. The classification of areas, elements, and occupants' activities will influence thermal comfort. This study took three sample houses as representations in Kampung Deret Petogogan, using in-depth interviews, observing the occupants' behavior, and research. This research aims to find answers using RISHA House in Kampung Deret Petogogan, whether it can provide thermal comfort standards effectively and efficiently for its inhabitants. This study's results are expected to be a guideline for the government to develop RISHA Houses in the future.
\end{abstract}

(c) 2020 IJBESR. All rights reserved.

Keywords: Body Behavior, Thermal Comfort, Activity, Kampung Deret Petogogan

\section{Introduction}

Comfort need for home, because most of the time spent on activities from work, even for small things like sleep that we have been doing, is inside the house. All the senses in the body seem to be a silent witness for different comfort for everyone. It cannot be denied that the body requires energy from the natural surroundings. Thermal comfort can be interpreted as satisfaction with the thermal environment expressed through the human state of mind [1]. The physical environment of the building the most related for thermal comfort, Psychological and physiological activities are strictly related to this study. The windows that open can allow the wind and sunlight to enter the room makes the occupant feel comfortable and peaceful [2]. The everyday needs especially comfort human motivation to behave. Occupant safety, health, and efficiency are closely related to environmental conditions of interiority and thermal comfort in recent years. An essential architectural element that refers to comfort is a window. Natural ventilation provides good air quality for thermal comfort and saves energy used for energy transitions. Natural ventilation can also offer views and sunlight [3]. The building has an essential role in providing thermal comfort.

Still, thermal comfort is not only in physical form, but the most important thing is also all about encounters: between people, interior, exterior, feeling, and the stories about living in it. There is an exciting phenomenon in South Jakarta, and it is called Kampung Deret Petogogan. People's lives here have changed dramatically from various aspects, especially from the quality of the house. The emergence of harmful behavior in the community can start from issues arising at homes, such as the 
house's size and spatial arrangement, the occupant's needs, furniture, activity, even climate that can affect body behavior to adapt to getting thermal comfort. The houses were built illegally, with some sort of conditions like lack of sunlight, no air ventilation, lots of dirty corners, and many more. The government then began to conduct a program that we know as "Kampung Deret," changing all existing buildings into a prefabricated concrete system called RISHA House. Houses began to have many openings such as windows and rosters, which were sufficient, so people's everyday lives started to change, from layout furniture, zoning activities, and body behavior.

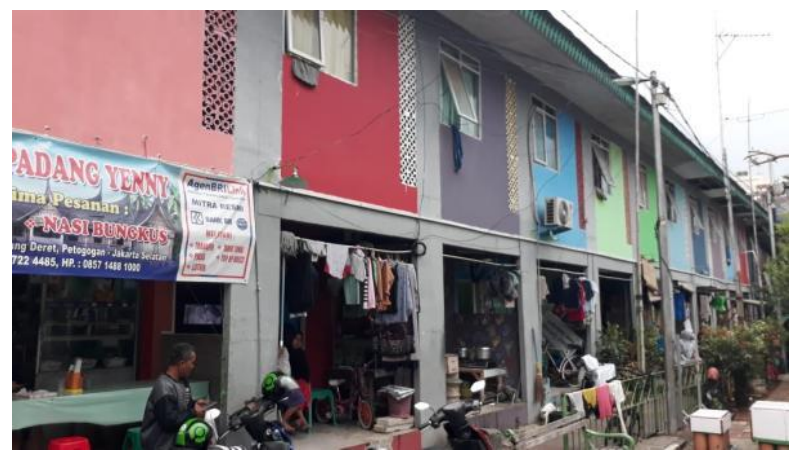

Source: (Author, 2020)

Figure 1: House in Kampung Deret Petogogan.

\subsection{Relationship Between Body Behavior and Thermal Comfort}

A person's emotional state drives bodily behavior, which reflects the individual. Movement of the body can be a valuable fundamental gesture to vent the emotions someone is feeling. Smiling is synonymous with happy people, and frowning is synonymous with sadness or anger [4]. Most people do not realize what their bodies are doing; sometimes, their behavior automatically moves independently. A gesture is a specific bodily movement that reinforces a verbal message or conveys a particular thought or emotion, sometimes made with the head, shoulder, or even the legs and feet. Still, most are made with the hand and arms [5]. Occupant behavior affects $80 \%$ of energy use. When occupants do not feel comfortable due to situation-specific, they are likely to change their body behavior to a certain level [6]. Not everyone has the same body behavior when dealing with something; The behavior of our bodies and moods following the context in which they occur can become more meaningful and understood [7]. So, the relation between the surrounding environment and body behavior is considered as one. "Every sense that functions according to its task, such as eyes to see, nose to smell, mouth to taste and ears to hear, imparts our knowledge and experience of the meaning of the world."[8]. Body behavior may provide clues as to the attitude or state of mind of a person; according to Arik Watson, "Body behavior is such science which put an effect on every part of our life. Factually Body Behavior is a system through which a person can know other people by seeing movements of one's body and can develop himself accordingly and make himself a successful person. Body behavior can also be an indicator of someone's thermal comfort [9]. When someone is in a hot place, exceeding the limits of the thermal comfort, they will immediately sweat and look for something that can produce wind.

Moreover, if someone is in a cold place, beyond the limits of thermal comfort, they will directly look for objects that can give them warmth, such as blankets, thick clothes, etc. The environment that increases human behavior's potential to appreciate someone is what the architect created a productive environment [10]. Humans are thermally comfortable when he cannot say whether he wants hotter or colder in the room. Comfort is human interaction and reaction to an environment free of taste, hostile, and subjective. Every human can have a different understanding of it, and activities also affect thermal comfort. Improve the environment's quality by actively and effectively modifying it to suit each individual's needs and collectively to be of 
higher quality than passively addressing the environment [11].

\subsection{Thermal Comfort Forces Body Behavior Adapting}

Jakarta, a tropical area, should pay attention to solar radiation's orientation and heat entering the room, increasing its cooling load and affecting thermal comfort [12]. According to Auliciems, A., \& Szokolay, S (2007), comfort is influenced by several factors, like air temperature, wind movement, humidity, radiation, subjective factors, such as metabolism, clothing, food and drinks, body shapes, as well as age and gender [13]. Air temperature is one of the most dominant factors in states of the thermal comfort of an environment. Each place's temperature is different because of several factors, such as sunlight, wind direction, altitude, clouds, and time. Humidity is also one of the essential elements for thermal comfort. Humidity is the water vapor contained in the air. Comfort limits in the equator range are between $22,5^{\circ} \mathrm{C}$ $29,5^{\circ} \mathrm{C}$ with relative humidity around $20 \%$ $50 \%$. Thermal comfort standards for humid tropical climates are minimal $22^{\circ} \mathrm{C} \mathrm{TE}$, maximal $24,5^{\circ} \mathrm{C}$ TE, and optimal $20,5^{\circ} \mathrm{C}$ TE (Temperature Effective). For comfortable humidity range about $40 \%-70 \%$. The temperature sensed by the occupants may not be the same in a living space with similar physical characteristics and equal temperature values.

According to social norms and expectations, each individual's comfort level will always change from time to time [14]. Modify conditions to find different temperatures like change clothing or activity level depends on the access to opportunities that will enable individuals to be more comfortable [15]. There are other aspects for thermal comfort occupants, by giving 'forgiveness,' so the occupants' attitude to the thermal comfort will overlook and be more ready [16]. The thermal comfort is also influenced by an individual's thermal sensitivity, which takes on different groups, includes the disabled, pregnant women, individuals under the age of fourteen, and over sixty are included in the adult coverage area [17].

Studies have found that males, on average, report discomfort due to temperature rises much earlier than females [18]. The occupants in Kampung Deret Petogogan are not passive concerning their thermal comfort but actively control it to secure comfort, which is hard to define and even harder to achieve. The most common complaint is that they are too hot. This would be simple if the second common complaint were hot also. Variability in indoor temperatures can be caused by action taken to reduce discomfort. What indicators make a person have a sufficient level of thermal comfort in RISHA House? Because there are more than 150 people each RT in Kampung Deret Petogogan. In everyday living spaces, the formation of architectural spaces can be established through everyday items [19]. The interior of everyday space becomes the manifestation of what occupants perceive, experience, and feel. It also reflects how the occupants use, occupy, and adapt to space [20]. This research will focus on the investigation through the body with thermal comfort based on daily activity.

\section{Material and Methods}

Thermal comfort is determined not only physically and physiologically but also psychologically. A study conducted in the last two decades identified the importance of adaptation for thermal comfort. Human adaptability includes three processes: behavior adaptation, adjustment through clothing, activity, body posture, food, and drink are behavioral adaptations (physical), physiological adaptations, and psychological adaptations [21]. One crucial element of thermal comfort is wind. Wind can be an 
indicator for less, more, or even enough for thermal comfort. When conducting a survey, it turns out there is one body behavior that the writer always does without realizing it as adaptation behavior in certain areas. Unwittingly, the writer keeps flapped his clothes with his hands to get more air when the air is too hot and makes it uncomfortable. There is a zoning pattern in the home due to bodily behavior: flapping clothes by hand. The flow of findings from the journey of flapping clothes from the beginning of entering the houses to the 2nd floor will be analyzed to find spaces. It can be a reference as a lack of thermal comfort at RISHA House in 3 houses in Kampung Deret Petogogan, house \#1, house \#3, and house \#5 is used as a sample to find the correlation be confirmed with data obtained using a Thermal hygrometer. The author surveyed 15 houses, but due to time constraints at the time of the survey, there were only three houses with complete data on the occupants' body behavior.

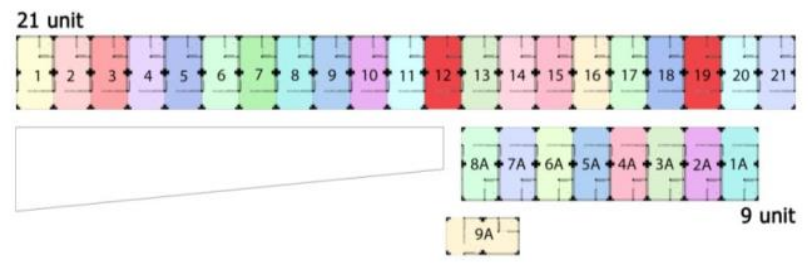

Source: (Author, 2020)

Figure 2: Key plan Kampung Deret Petogogan.

\section{Results and Discussions}

\subsection{The Establishment of Body Behavior for Thermal Comfort}

The level of thermal comfort in the RISHA House in this research can be understood automatically by body behavior that suddenly the author flapped clothes. This body behavior is found in some parts of the house, felt not following the thermal comfort. The occupants divide their house zoning into two zonings, first zoning is for service area with some activities like cooking, washing clothes, drying clothes, toilet, and storage. At the same time, the other zoning is for resting areas like sleeping and relaxing activities. These differences in activity will affect body behavior between each zoning that we will study here.
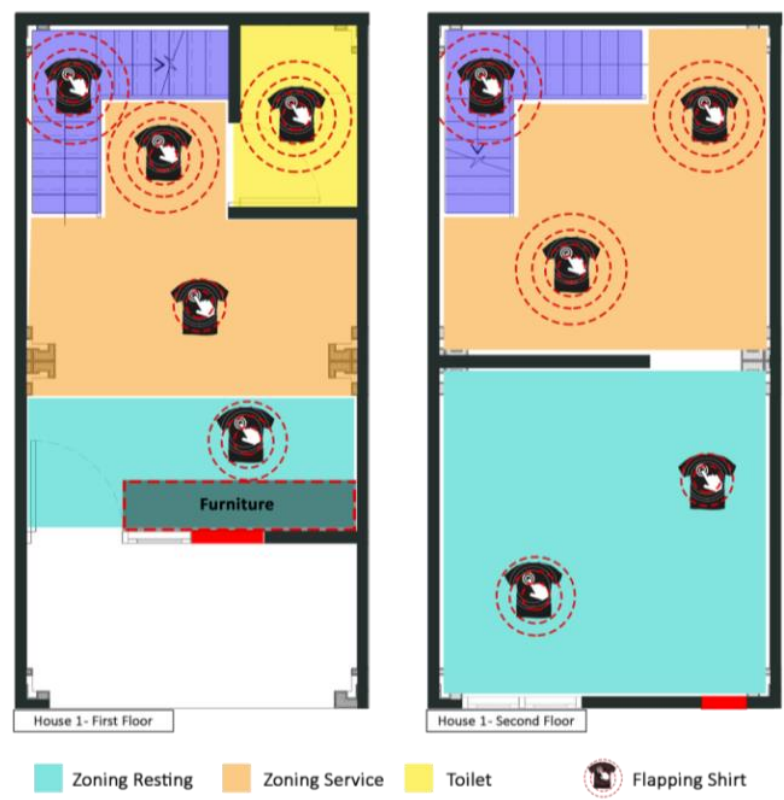

Source: (Author, 2020)

Figure 3: Position of flapped clothes in House \#1.

In house \#1, when entering the house through the entrance, fresh air is still felt even though it is only from the entrance door and rosters because the window is getting closed by furniture. However, when the author was at the closed window's back, the heat began to feel and slightly flapped his clothes. After having a conversation for a while with the occupants, the author sweat started to come out. He automatically began to flap his clothes harder to get fresh air, the toilet that had no openings at all, can you imagine it? It feels very stuffy. The deeper in the house, the hotter and sweatier it gets. After that, the author headed to the second floor and immediately welcomed with hot air because there is a barrier wall first and no openings at the back, so the hot air always rotates at the end of the house. After passing through the barrier wall, the author's body finally started to feel the fresh air from the front window area, even though it was only a little 
slight because the curtains blocked it, but the author had begun to reduce flapped his shirt.

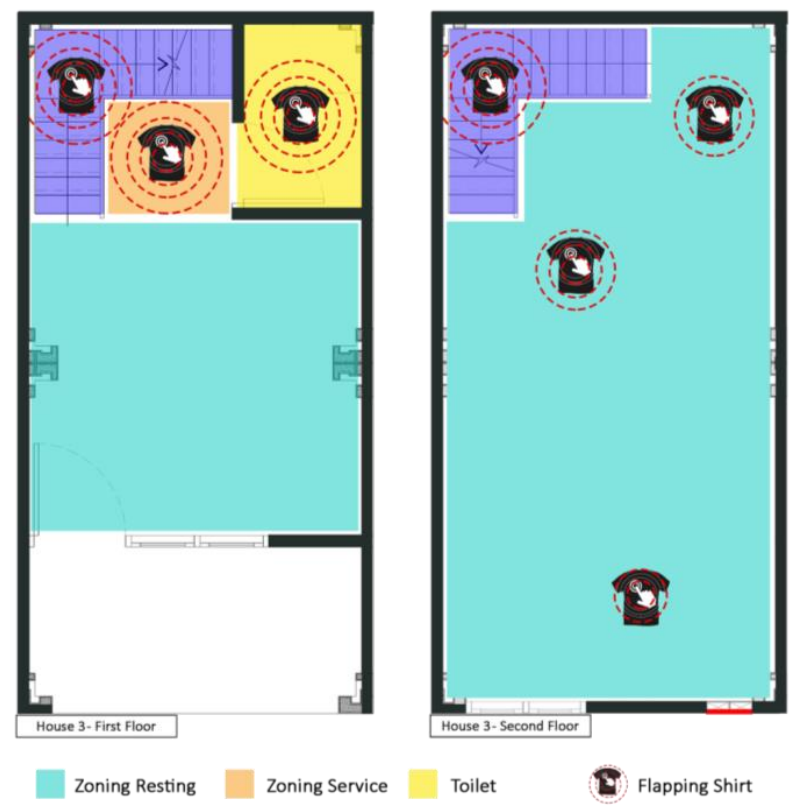

Source: (Author, 2020)

Figure 4: Position of flapped clothes in House \#3.

In house \#3, the air feels quite comfortable because the natural ventilation is used to its potential. Although the author has been sitting for a while with the occupants in the front area, it still feels comfortable because of the fresh air from the window, rosters, and even the entrance door. Getting deeper into the service area, the heat began to disturb the comfort, and the author began to flap his clothes, especially in the toilet, the author flapped his clothes even harder because there are no openings at all. Up to the second floor, the heat began to increase in the area stair, and the very back into the front in the house was very uncomfortable and stuffy due lack of fresh air because half of the rosters are being closed and the window blocked by curtains, made the author flapped his clothes while on the second floor. The occupants often use the floor as a base to increase thermal comfort.

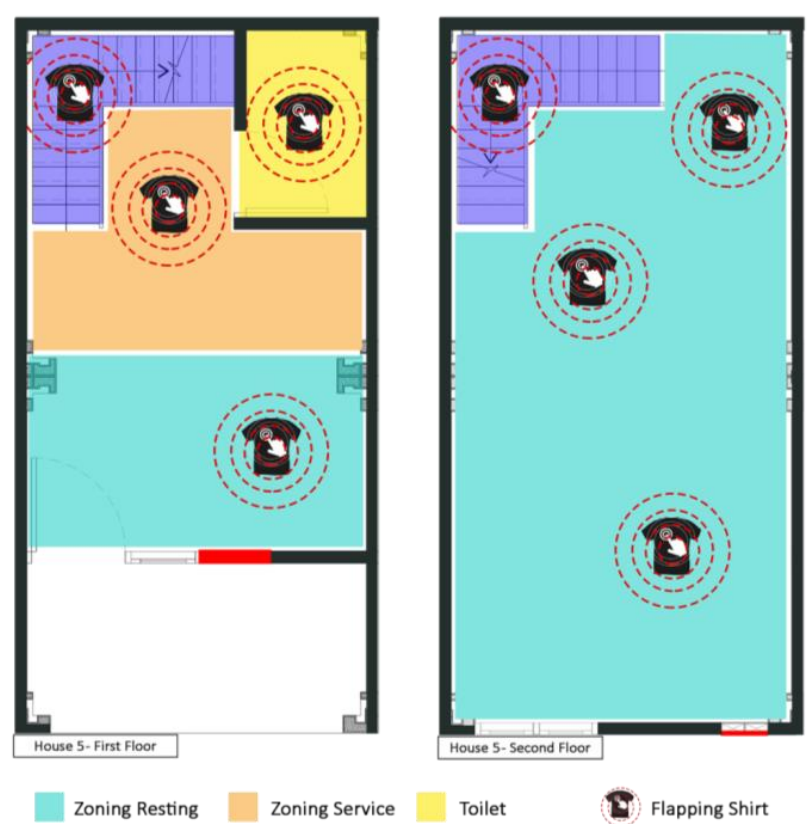

Source: (Author, 2020)

Figure 5: Position of flapped clothes in House \#5.

In house \#5, from the beginning of entering the house, the author already started to flap his clothes because it feels uncomfortable, until the occupants who live in turned on the fan. Allnatural ventilation is closed from the window and rosters. The Occupants only expect fresh air to come from the front door, but it turns out there is a cupboard in front of the door that prevents the wind from coming inside. In the service area, the author's thermal comfort decreases again, because just like other houses, the back of the house has no openings. Just like the first floor, the second floor also feels uncomfortable. While inside this house, the author keeps flapped his clothes often, the rosters were closed down, and the window got blocked by the bed, made the author's thermal comfort disappear. Overall, all the houses sampled are not thermally comfortable through body behavior. 


\subsection{Natural Ventilation Increases Thermal Comfort}

Natural ventilation has dominated human life in terms of indoor activities. Humans need fresh air, so if a room does not have proper natural ventilation, it can get rid of the comfortable feeling. Some advantages of having natural ventilation include reducing energy and operation costs, better indoor air quality, a healthier and more productive environment [22]. Using the wind's natural force by distributing incoming fresh air effectively through natural ventilation provides a fresh, healthy, and comfortable indoor environment for residents to live and do other activities. Natural ventilation can provide environmental conditions in the room that can increase occupant productivity by reducing healthcare costs and reducing absenteeism. Natural ventilation is a passive cooling method that has significant potential to reduce building energy consumption and to contribute to indoor environmental conditions positively [23].

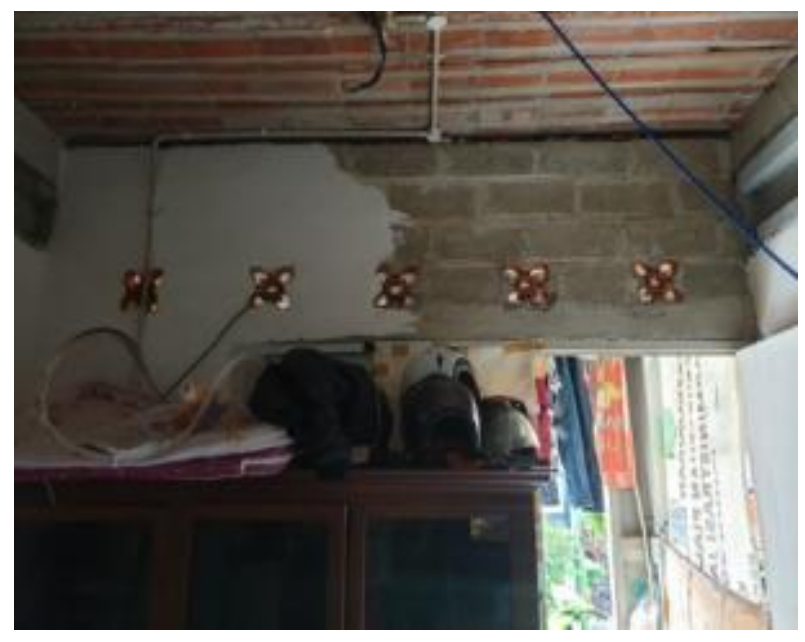

Source: (Author, 2020)

Figure 6: Existing Natural Ventilation First Floor.

Imagine how efficient natural ventilation is at RISHA House. However, according to some occupants, it turns out that many changes have been made like close some windows and rosters for other needs, so the thermal comfort in some parts of the house is getting reduced and changed the body behavior of the occupants. The difference in thermal comfort in every part of the house known from the flapped shirt method is similar in that the natural ventilation has a significant impact. When we sit and talk near and open window or open rosters, the wind flow will provide thermal comfort, and by closing or reducing the natural ventilation that was initially planned to be opened will have a significant influence on thermal comfort. The window is the best source of fresh air. Houses in the Kampung Deret Petogogan were initially well ventilated, but over time, changes began to occur due to different occupants' needs. There are many various reasons and stories for this change.

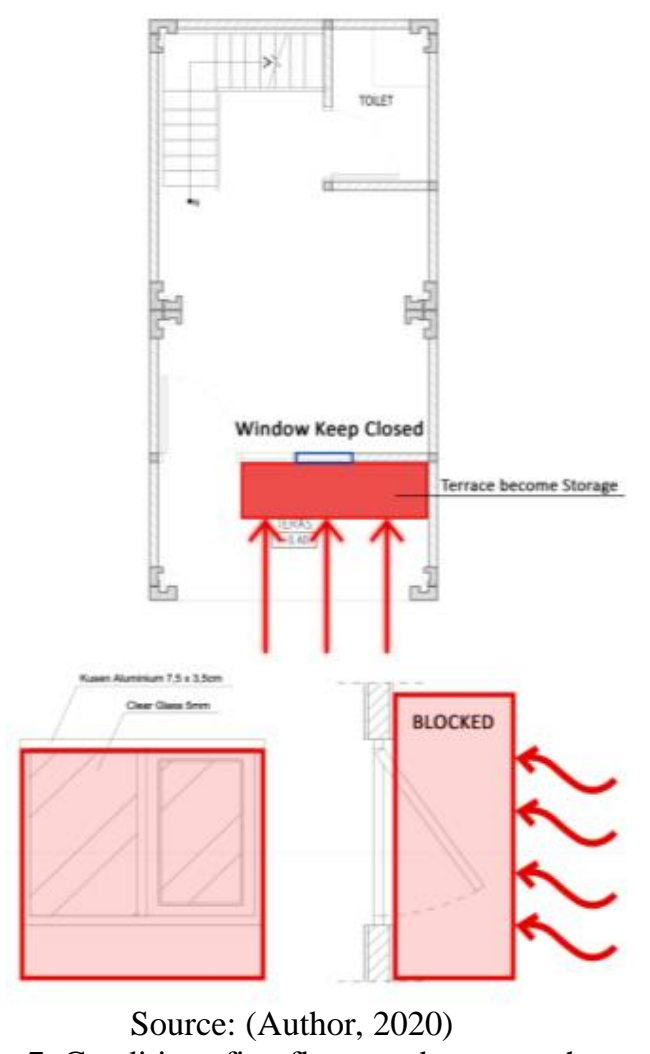

Figure 7: Conditions first floor used as a warehouse.

Thermal comfort can be obtained from a combination of several aspects, and all have their respective roles. In this case, the change occurred because of aspects of the need for natural conditions like rainwater leaked and lack of space, so some natural ventilation was even closed. For the first floor, the front of the 
windows is used as a warehouse due to lack of space. The type of window on the first floor is swing front; if in front of the windows, there are blocked things, then the windows can not be opened.

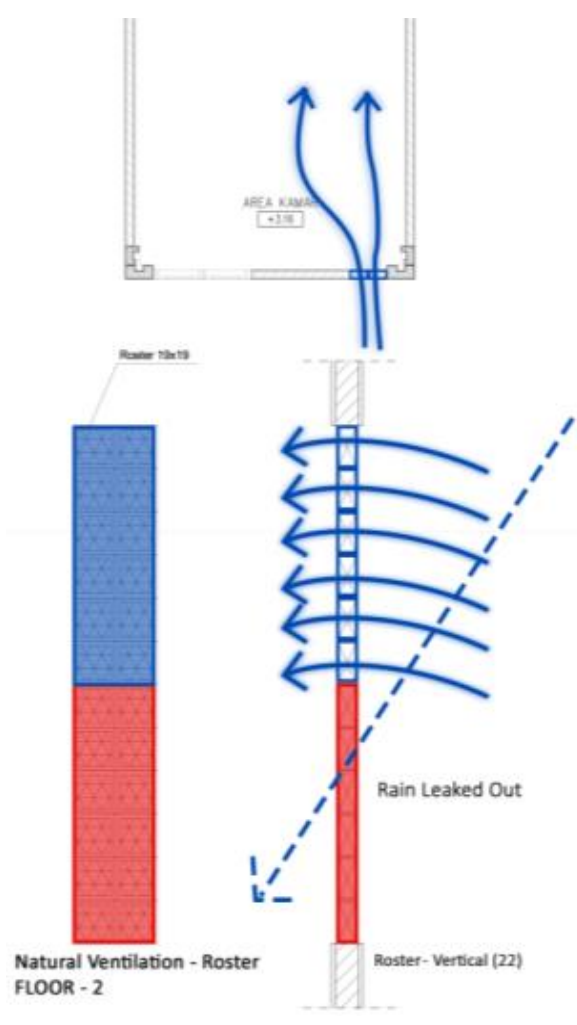

Source: (Author, 2020)

Figure 8: Conditions second floor's roster got closed.

\subsection{Cross-Check Through Subjective Measurement (Occupants'Body Behavior)}

Further analysis of thermal comfort through body behavior shows that the occupants' several activities to increase their thermal comfort in space.

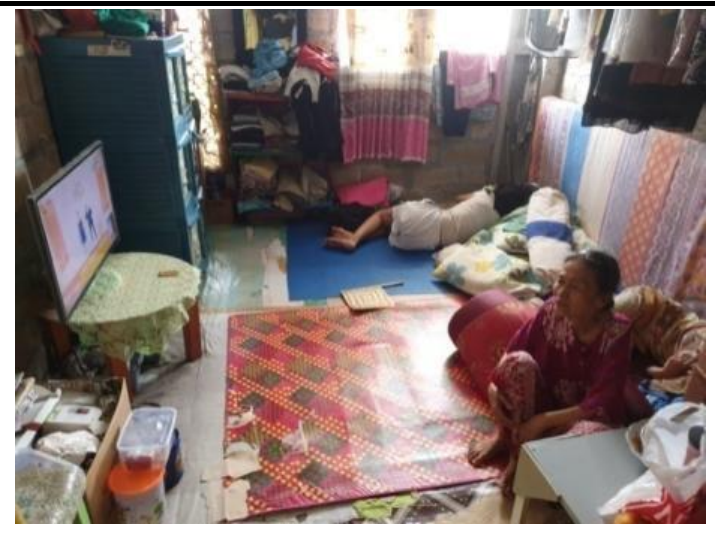

Source: (Author, 2020)

Figure 9: Sleep and sit on the floor during the day.

Through the thermal analysis, building materials significantly affect the indoor air temperatures [24]. During the day, the activities of the occupants in Kampung Deret Petogogan is resting. RISHA House has a floor with ceramic material made of clay; in other words, the ceramic material does not hold the heat so that ceramics can remain cold even though the surrounding air is hot. The occupants use it to provide thermal comfort. On the first floor, the occupants use a thin floor mat during the daytime, while on the second floor, the mattress is folded so that the occupants can touch closer to the floor.

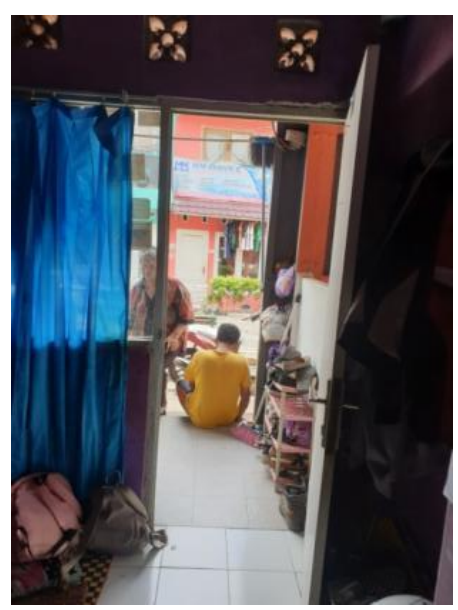

Source: (Author, 2020)

Figure 10: The door always opens during the day.

Much natural ventilation is closed due to other interests, so the occupants use the entrance door as a natural ventilation device. The door always 
opens in the morning, even at night during bedtime; the door is opened slightly to provide fresh air to increase thermal comfort. Spaces that do not have natural ventilation, such as in the back of the house (service area) and sleeping area on the second floor, because the activities always influence thermal comfort. To increase thermal comfort, the occupants add fans. In one house, the occupants can have even two to four fans. Daily activities have an essential role to play in understanding the supportive interactions that occur and preventing interiority [25]. The occupants also spend more time on the terrace during the day and gather with neighbors, besides to socialize and get fresh air that comes directly from outside. Thermal comfort for each occupant can be felt differently, even though the atmosphere projected is the same, such as space and place [26]. Occupant's body behavior can identify areas that do not have thermal comfort and force the body's behavior to seek thermal comfort in various ways.

\subsection{Cross-Check Through Objective Measurement}

Objective and subjective measurements evaluate the thermal comfort for an accurate measure in the house using a tool to get the data. Overall, from this survey's data, the average humidity from 15 samples house is around $66 \% / 33^{\circ}$ on the first floor and $67 \% / 34^{\circ}$ on the second floor. The right humidity level is essential for our health and comfort, which must be maintained around 45\%-64\%. The level of humidity in the room is more easily changed, depending on the occupants' activities.
Table 1: Humidity of each house.

\begin{tabular}{|c|c|c|c|c|c|c|c|}
\hline \multirow[t]{2}{*}{ No } & \multirow{2}{*}{$\begin{array}{l}\text { Hummidity } \\
\text { First Floor } \\
\% /{ }^{\circ} \mathrm{C} \\
\end{array}$} & \multirow{2}{*}{ 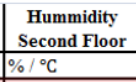 } & \multirow{2}{*}{$\begin{array}{c}\text { Pengudaraan } \\
\text { Buatan? }\end{array}$} & \multicolumn{2}{|c|}{ Roster Closed? } & \multicolumn{2}{|c|}{ Window Closed? } \\
\hline & & & & 1st Floor & 2nd Floor & 1st Floor & 2nd Floor \\
\hline 1 & $60 \% / 32^{\circ} \mathrm{C}$ & $65 \% / 33^{\circ} \mathrm{C}$ & \begin{tabular}{|l|} 
Lt $1:$ No \\
Lt $2:$ AC \& Fan
\end{tabular} & No & YES & YES & NO \\
\hline 2 & $65 \% / 34^{\circ} \mathrm{C}$ & $67 \% / 34^{\circ} \mathrm{C}$ & \begin{tabular}{|l|} 
Lt $1:$ Fan \& \\
exhaust fan \\
Lt $2:$ Fan \\
\end{tabular} & YES & $1 / 2$ & $\begin{array}{c}\text { No } \\
\text { Window }\end{array}$ & No \\
\hline 3 & $72 \% / 32^{\circ} \mathrm{C}$ & $69 \% / 33^{\circ} \mathrm{C}$ & $\begin{array}{l}\text { Lt } 1: \text { Fan } \\
\text { Lt } 2: \text { Fan } \\
\end{array}$ & No & $1 / 2$ & YES & No \\
\hline 4 & & & & & & & \\
\hline 5 & $66 \% / 34^{\circ} \mathrm{C}$ & $67 \% / 34^{\circ} \mathrm{C}$ & \begin{tabular}{|l|} 
Lt $1:$ Fan \\
Lt $2:$ AC \& Fan
\end{tabular} & YES & YES & YES & YES \\
\hline 6 & $68 \% / 34^{\circ} \mathrm{C}$ & $68 \% / 34^{\circ} \mathrm{C}$ & $\begin{array}{l}\text { Lt } 1: \text { NO } \\
\text { Lt } 2: \text { Fan } \\
\end{array}$ & No & YES & YES & No \\
\hline 7 & & & & & & & \\
\hline 8 & $73 \% / 31^{\circ} \mathrm{C}$ & $63 \% / 34^{\circ} \mathrm{C}$ & $\begin{array}{l}\text { Lt } 1: \text { Fan } \\
\text { Lt } 2: \text { Fan } \\
\end{array}$ & No & YES & YES & No \\
\hline 9 & $64 \% / 35^{\circ} \mathrm{C}$ & $65 \% / 34^{\circ} \mathrm{C}$ & $\begin{array}{l}\text { Lt } 1: \text { Fan } \\
\text { Lt } 2: \text { Fan }\end{array}$ & No & YES & YES & YES \\
\hline 10 & $64 \% / 34^{\circ} \mathrm{C}$ & $65 \% / 34^{\circ} \mathrm{C}$ & $\begin{array}{l}\text { Lt } 1: \text { Fan } \\
\text { Lt } 2: \text { Fan } \\
\end{array}$ & No & No & YES & No \\
\hline 11 & $65 \% / 33^{\circ} \mathrm{C}$ & $69 \% / 33^{\circ} \mathrm{C}$ & \begin{tabular}{|l|} 
Lt $1:$ Fan \\
Lt $2:$ Fan
\end{tabular} & No & $1 / 2$ & No & No \\
\hline 12 & $66 \% / 34^{\circ} \mathrm{C}$ & $68 \% / 34^{\circ} \mathrm{C}$ & $\begin{array}{l}\text { Lt } 1: \text { Fan } \\
\text { Lt } 2: \text { Fan } \\
\end{array}$ & No & YES & No & No \\
\hline 13 & $68 \% / 35^{\circ} \mathrm{C}$ & $65 \% / 35^{\circ} \mathrm{C}$ & $\begin{array}{l}\text { Lt } 1: \text { Fan } \\
\text { Lt } 2: \text { Fan } \\
\end{array}$ & No & NO & YES & No \\
\hline 14 & $71 \% / 35^{\circ} \mathrm{C}$ & $68 \% / 34^{\circ} \mathrm{C}$ & $\begin{array}{l}\text { Lt } 1: \text { Fan } \\
\text { Lt } 2: \text { Fan } \\
\end{array}$ & No & YES & YES & YES \\
\hline 15 & $68 \% / 33^{\circ} \mathrm{C}$ & $71 \% / 33^{\circ} \mathrm{C}$ & \begin{tabular}{|l|} 
Lt $1:$ Fan \\
Lt $2: A C \&$ Fan \\
\end{tabular} & No & YES & YES & YES \\
\hline 16 & & & & & & & \\
\hline 17 & & & & & & & \\
\hline 18 & $65 \% / 34^{\circ} \mathrm{C}$ & $65 \% / 34^{\circ} \mathrm{C}$ & \begin{tabular}{|l|} 
Lt $1:$ Fan \\
Lt $2:$ Fan \\
\end{tabular} & YES & YES & NO & NO \\
\hline 19 & $60 \% / 35^{\circ} \mathrm{C}$ & No Permission & \begin{tabular}{|l} 
Lt $1:$ Fan \\
Lt $2:$ AC \& Fan
\end{tabular} & NO & - & No & NO \\
\hline
\end{tabular}

Source: (Author, 2020)

Results from subjective research through body behavior then do a cross-check to ensure the house's thermal comfort conditions with objective measurements. It can be said that thermal comfort at the house in Kampung Deret Petogogan can be said to be thermally uncomfortable. The existence of radiation and convection modes between the occupants and the surrounding environment, which results in the exchange of heat loads, is a significant source of thermal discomfort [27]. The first step in providing a passive solution to reducing thermal discomfort is knowing the temperature people feel in their house and the tolerance for occupants' boundaries. [28]. The most frequent activities that have been done by the occupants are washing and cooking because most of the occupants have a profession as a housewife. So that humidity changes are apparent here, such as moldy walls and paint that starts to peel. 


\subsection{Thermal Comfort Through Body Behavior}

The body behavior of thermal comfort brings into question how people get thermal comfort from body behavior - activities, conditions, and situations. Is it only when the person feels neither too cold nor too warm? If the temperature in the room is following the standard? No, it is not thermal comfort is more than just a number. Many aspects of everyday life will change the basic principles of thermal comfort. For example, an occupant in Kampung Deret Petogogan who at the beginning thermally comfortable than doing activities such as cooking, washing and drying will make thermal comfort decrease or got disturbed and sweat will begin to wet his body, the hot temperature begins to overwhelm their body, and they will look for a way to regain their thermal comfort from various things, like taking a short break, drinking cold water, finding more cooling tools, flapping their shirt to get wind, and even sit right on the floor. Everyday experiences that have become a habit will be difficult to capture everyday experiences because they have become mundane [29]. Personal factors for thermal comfort are dependent on the isolating effect of clothing on the wearer [30]. It is essential to identify how the clothing contributes to thermal comfort or discomfort if you are wearing clothes that are too thick during the environment is considered hot; it causes you to heat stress. If the isolation provided by clothes is not sufficient, the body can get sick because of the cold. Thermal comfort is a complicated relationship between air temperature, air humidity, airflow velocity, and the type of clothing with activity and the occupant's metabolic rate, which presents an expression of feeling satisfaction [31]. Thermal comfort is interpreted as thermal neutrality, which means that a person feels neither too cold nor too hot. Nothing lasts for thermal comfort, and everything can be changed from many factors.

\section{Conclusion}

The level of comfort depends on the perception of each individual that is influenced by human behavior. RISHA house was designed to have enough original airing from window openings, and rosters began to lose their function due to closure and reduction to meet residents' storage space requirements. Occupants will develop the quality of existing space in their own homes to support comfort needs. Of course, the air conditioner will solve every problem but by asking for backup energy. The most important is only published, which is not a rare condition that causes thermal comfort; more important are the requirements. Thermal comfort for occupants varies significantly according to culture, age, clothing, gender, and health. Agreement in identifying the boundaries of space formed from a person's thermal discomfort with bodily behavior is flapping clothes. Clothes are things we can find even though we use them every day; It turns out to be a tool to identify thermal comfort in a room. Body behavior - flapping clothes automatically is the identification of thermally uncomfortable areas. This method is undoubtedly carried out by everyone when their thermal comfort is disrupted - the relationship between thermal comfort and flapping clothes is proof that space's quality is not comfortable. Hence, clothes have an essential role in people's thermal comfort who have also been confirmed by using Thermal hygrometer measuring instruments. Activities by residents can be judges for individual thermal comfort. RISHA's house in Kampung Deret Petogogan that does not have enough natural ventilation, due to the closure that occurs will make the house uncomfortable. Areas where many energy-consuming activities occur to decrease the thermal comfort of people who need fresh air. Identifying the parts of the house that are uncomfortable will help us find ways to improve thermal comfort. This method's strength is that we will know a person's thermal comfort only from bodily behavior: Flapping 
Clothes. This shows that the body's behavior will automatically find a way to get out of discomfort to get thermal comfort. This research informs that part of the house that is getting deeper will be in line with the increasing thermal discomfort at home. To increase thermal comfort at RISHA house, the government can do several ways, such as; 1 . Collaborate with residents to discuss in advance the need for storage space for goods. The use of multifunctional furniture, with the addition of the function as a place to store goods, lets the natural openings work following their functions; 2. The use of rosters (permanent openings) replaced by nako windows (flexible) allows residents to adjust the natural openings according to circumstances' needs; 3 . Replacing the hinged window into a sliding window will save space usage and maximize window openings. The relationship between physical devices and the human mind with bodily behavior plays a more significant role than what we expect - playing a specific part that creates 'Thermal Comfort.'

\section{Acknowledgment}

Thanks to all the informants in Kampung Deret Petogogan for their information, cooperation, and time.

\section{References}

[1] Dear, D., Richard, Brager, G. S. 1998. Developing an Adaptive Model of Thermal Comfort and Preference. ASHRAE Transactions, Vol 104 (1), pp. 145-167.

[2] Biner, P. M., Butler, D.L., Lovegrove, T. E., Burns, R.L., 1993. Windowless in the workplace: A reexamination of the compensation hypothesis. Environment and Behavior, 25, (2), 205-227.

[3] Feustel, H., Stetiu, C. 1995. Hydronic radiant coolingpreliminary assessment, Energy and Buildings 22(3) (1995) 193-205.

[4] Allan \& Pease, B., 2004. The Definitive Book of Body Language. Australia; Pease International.

[5] Smedley, C., 2004. Gesture: Your Body Speaks. USA; Toastmasters International.

[6] Tohoku University. 2013. Annex 53 Total energy use in buildings. Sendai, Japan: International Energy Agency.
[7] Bell, P. A., Greene, T.C., Fisher, J. D., Baum, A. 1996, "Environmental Psychology" Fourth Edition, Holt, Rinehart, and Winston, Inc., USA.

[8] Atkinson, R. L., 1996. Hilgard's Introduction to Psychology, Twelfth Edition, Harcourt Brace \& Company, USA.

[9] Watson, A., 2010. Know and Learn: Body Language. [10] Jon, L. 1987. Creating Architectural Theory: The Role of the Behavioral Sciences in Environmental Design, Van Nostrand Reinhold Company, USA.

[11] Sommer, R. 1974. Looking back at personal space. In J.Lang (Ed), Designing for Human Behavior. Architecture and the Behavioral Sciences (pp. 202-209). Stroudsburg, Pa.: Dowden, Hutchinson, and Ross.

[12] Chandra, B., Siwi, S.H., Priyomarsono, N.W., Lianto, F. 2019. Determining the Most Important Factors in House Design with Net Zero Energy Concept (Case study: Cluster X, Perumahan Y, Gading Serpong, Tangerang). International Journal of Built Environment and Scientific Research. IJBESR, Vol 03 No 02: 99-104 [13] Auliciems, A., \& Szokolay, S. 2007. Thermal Comfort. 2nd Revised Edition, Brisbane, PLEA: Passive and Low Energy Architecture International in association with Department of Architecture, The University of Queensland.

[14] Chappells, H \& Shove, E. 2007. Debating the Future of Comfort: Environmental Sustainability, Energy Consumption, and The Indoor Environment. Building Research \& information, 32-40.

[15] Cole, Robinson, J., Brown, Z., O'seha, M. 2008. Recontextualizing The Notion of Comfort. Building Research \& Information, 36, (4), 323 - 336.

[16] Leaman \& Bordas. 2010. Productivity in Buildings:

The 'Killer' Variables. Building Research and Information. 1 (1): 4-19.

[17] Lenzuni, P., Freda, D., Gaudio, D.M. 2009.Classification of Thermal Environments for Comfort Assessment. Annals of Occupational Hygiene. 53 (4): 325-32.

[18] Wyon, D. P., Andersen, I., Lundqvist, GR 2009. Spontaneous magnitude estimation of thermal discomfort during changes in the ambient temperature. Journal of Hygiene. 70 (2): 203-21.

[19] Yudistira, F., \& Yatmo, Y. A., Atmodiwirjo, P. 2019. From Rigidity to Ephemerality: Architecture as a Socio-spatial Assemblage of Heterogeneous Components. A/Z ITU Journal of Faculty of Architecture, Volume 16(3), pp. 115-129.

[20] Atmodiwirjo, P., \& Yao, Y. 2019. Interiority in Everyday Space: A Dialogue between Materiality and Occupation. Interiority, 2(1), 1-4.

[21] Nikolopoulou \& Steemers. 2003. Thermal Comfort and Psychological Adaptation as a Guide for Designing Urban Spaces. Energy and Buildings 35 (1): 95-101.

[22] Steven, J., Emmerich, W., Dols, S., James, W., Axley. 2001. Natural Ventilation Review and Plan for 
Design and Analysis Tools. National Institute of Standards and Technology. NISTIR 6781.

[23] Jindong, W. 2015. Thermal Comfort and Occupant Behavior in Office Buildings in South-East China. Ph.D. Thesis, University of Nottingham.

[24] Stafford, L. 2019. Contested Interiority: Sense of Outsideness/Insideness Conveyed through Everyday Interactions with University Campus Doors. Interiority, 2(1), 25-41.

[25] Nir'aini, R. D. 2017. Thermal Performance Simulation of Residential Building in Tropical Climate Case Study: Housing in Bandar Universiti, Malaysia. International Journal of Built Environment and Scientific Research. IJBESR, Vol 01 No 01: 47-52

[26]. Putra, A. P. D \& Lukito, Y. N. 2018. Architect and Empathy: The Importance of Human Experience in Architectural Design. International Journal of Built Environment and Scientific Research, Vol. 02, No. 01, 47-54.

[27] Ghany, A.M. 2013. Human Thermal Comfort and Heat Stress in an Outdoor Urban Arid Environment: A Case Study. Hindawi. Advances in Meteorology, Vol 2013, ID 693541.

[28] Adaji, Michael, Watkins, Richard, Adler, Gerald. 2015. An Investigation into Thermal Comfort in Residential Buildings in the Hot-Humid Climate of SubSaharan Africa: A Field Study in Abuja-Nigeria. IN: Proceedings of 31st International PLEA Conference, Passive Low Energy Architecture: Architecture in (R) Evolution.

[29] Finlay, L. 2011. Phenomenology for therapists: Research the lived world. Oxford: John Wiley \& Sons.

[30] Ogata, T. 2007. The Effect of Thermal Insulation of Clothing on Human Thermal Comfort. Cukurova University.

[31] ISO Standard (International Standard Organization). 2005. Ergonomics of the thermal environmentAnalytical determination and interpretation of thermal comfort using calculation of the PMV and PPD Indices and local thermal comfort criteria. ISO 7730:2005 (E). 
(This page is intentionally left blank) 